\title{
PENERAPAN MODEL PEMBELAJARAN \\ LEARNING CYCLE "5E" BERBANTUAN LKS TERSTRUKTUR UNTUK \\ MENINGKATKAN KEMAMPUAN PENALARAN \\ DAN KOMUNIKASI MATEMATIKA
}

\author{
Putu Suarniti Noviantari \\ Program Studi Pendidikan Matematika, Fakultas Keguruan Dan Ilmu Pendidikan \\ Universitas Mahasaraswati Denpasar
}

\begin{abstract}
ABSTRAK
Penelitian ini bertujuan untuk (1) meningkatkan kemampuan penalaran dan komunikasi matematika siswa Kelas VIIIA SMP Negeri 3 Karangasem dan (2) mengetahui respons siswa terhadap penerapan model pembelajaran Learning Cycle " $5 \mathrm{E}$ " berbantuan LKS terstruktur. Jenis penelitian ini adalah penelitian tindakan kelas yang terdiri dari tiga siklus. Setiap siklus terdiri dari tahap perencanaan, pelaksanaan tindakan, observasi/evaluasi, dan refleksi. Subjek penelitian ini adalah siswa Kelas VIIIA SMP Negeri 3 Karangasem tahun ajaran 2013/2014 sebanyak 30 orang. Data kemampuan tentang kemampuan penalaran dan komunikasi matematika siswa dikumpulkan melalui tes berbentuk uraian dan data tentang respons siswa dikumpulkan melalui angket. Data-data yang dikumpulkan dianalisis menggunakan analisis deskriptif. Hasil penelitian menunjukkan bahwa implementasi model Learning Cycle "5E" berbantuan LKS terstruktur, dapat meningkatkan kemampuan penalaran dan komunikasi matematika siswa Kelas VIIIA SMP Negeri 3 Karangasem, yaitu dari rata-rata 23,06 (cukup baik) pada siklus I menjadi 28,57 (baik) pada siklus II, dan 34,2 (sangat baik) pada siklus III. Siswa memberikan respons yang sangat positif terhadap implementasi model pembelajaran Learning Cycle "5E" berbantuan LKS terstruktur dengan nilai rata-rata sebesar 35,7.
\end{abstract}

Kata kunci: model pembelajaran Learning Cycle "5E", LKS terstruktur, kemampuan penalaran dan komunikasi matematika.

\begin{abstract}
This study aimed at (1) improving the math reasoning and communicating skill of VIIIA students at SMP Negeri 3 Karangasem and (2) investigating the students' responses towards the implementation of 5E Learning Cycle model assisted by structured student worksheet. This study was a classroom action research whisch was conducted in 3 cycles. Each cycle consisted of planning phase, action phase, observation/evaluation phase, and reflection phase. The subject of the study was 30 VIIIA students at SMP Negeri 3 Karangasem in the academic year 2013/2014. Math reasoning and communicating skill data were gathered through an essay test and the students' response data was collected through a questionnaire. Afterwards, the data was analyzed by means of descriptive analysis. The findings revealed that the implementation of 5E Learning Cycle model assisted by structured student worksheet was able to improve the math reasoning and communicating skill of VIIIA students at SMP Negeri 3 Karangasem. It was proven by the mean score 23.06 (quite good) in cycle I turned into 28.57 (good) in cycle II, and it turned into 34.2 (very good) in
\end{abstract}


cycle III. The students gave positive responses towards the implementation of $5 \mathrm{E}$ Learning Cycle model assisted by structured student worksheet which was proven by the mean score 35.7 .

Keywords: 5E Learning Cycle model, structured student worksheet, math reasoning and communicating skill.

\section{PENDAHULUAN}

Pada awalnya pembelajaran matematika di sekolah bertujuan untuk mempersiapkan siswa agar dapat menggunakan matematika dan pola pikir matematika dalam kehidupan sehari-hari dan dalam mempelajari berbagai ilmu (Depdiknas, 2004), namun dewasa ini tujuan pembelajaran matematika sekolah telah difokuskan pada empat tujuan utama, yaitu: 1) melatih cara berpikir dan bernalar, 2) mengembangkan kemampuan berpikir divergen, 3) mengembangkan kemampuan menyampaikan informasi atau mengomunikasikan gagasan, dan 4) mengembangkan kemampuan pemecahan masalah dan membuat dugaan (Subando, 2005). Salah satu dari tujuan pembelajaran matematika di atas adalah melatih cara berpikir dan bernalar. Siswa diharapkan menggunakan penalaran dalam membuat generalisasi, menyusun bukti, atau menjelaskan gagasan dan pernyataan matematika. Penalaran matematika adalah suatu cara berpikir yang sistematis, logis, dalam pemecahan masalah matematika (Depdiknas, 2004). Orang-orang bernalar cenderung mencatat polapola, struktur-struktur, atau kebiasaankebiasaan dalam situasi nyata. Penalaran siswa biasanya terlihat pada kemampuan siswa menganalisis masalah-masalah yang dihadapi untuk mendapatkan penyelesaian yang logis (Mahayukti dan Suharta, 2003)

\begin{tabular}{lrr}
\multicolumn{1}{c}{ Tujuan yang lain dalam } \\
pembelajaran matematika & adalah \\
mengembangkan & \multicolumn{2}{c}{ kemampuan } \\
menyampaikan & informasi atau
\end{tabular}
mengomunikasikan gagasan. NCTM (dalam Ansari, 2003) menyatakan bahwa komunikasi matematika merupakan kemampuan dalam hal menjelaskan suatu algoritma dan cara unik untuk pemecahan masalah, kemampuan siswa mengonstruksi dan menjelaskan sajian fenomena dunia nyata secara grafik, kata-kata/kalimat, persamaan, tabel dan sajian secara fisik atau kemampuan siswa memberikan dugaan tentang gambar geometri. Penalaran dan komunikasi merupakan dua kemampuan umum 
yang sangat dekat. Kemampuan penalaran dan komunikasi matematika sangatlah diperlukan dalam mata pelajaran matematika karena orang yang memiliki kemampuan penalaran yang tinggi serta mampu mengomunikasikan ide atau gagasan matematikanya dengan baik cenderung mempunyai pemahaman yang baik terhadap konsep yang dipelajari serta mampu memecahkan permasalahan yang berkaitan dengan konsep yang dipelajari yang nantinya akan berpengaruh pada hasil belajar siswa.

\section{Rendahnya kemampuan} penalaran dan komunikasi matematika diduga disebabkan oleh penekanan pembelajaran di kelas yang masih menekankan pada keterampilan mengerjakan soal (drill), sehingga kurang memberikan kesempatan kepada siswa untuk membangun sendiri pengetahuan yang mereka miliki. Hal ini mengakibatkan siswa kurang terbiasa mengerjakan soal-soal pemecahan masalah yang menuntut mereka untuk bernalar dan mengomunikasikan ide-idenya. Rendahnya kemampuan penalaran dan komunikasi matematika siswa juga ditemui di kelas VIIIA SMP Negeri 3 Karangasem. Hal ini terlihat dari data nilai raport di kelas VIIIA untuk aspek penalaran dan komunikasi matematika selama 3 tahun terakhir.

\section{Tabel 1. Nilai Rata-rata Kelas VIIIA untuk Nilai Kemampuan Penalaran dan Komunikasi}

\begin{tabular}{cclc}
\hline No. & $\begin{array}{c}\text { Tahun } \\
\text { Pelajaran }\end{array}$ & Semester & $\begin{array}{c}\text { Rata- } \\
\text { rata } \\
\text { Kelas }\end{array}$ \\
\hline 1 & $2010 / 2011$ & Ganjil & 64,25 \\
\cline { 3 - 4 } & & Genap & 65,99 \\
\hline 2 & $2011 / 2012$ & Ganjil & 66,45 \\
\cline { 3 - 4 } & & Genap & 68,05 \\
\hline 3 & $2012 / 2013$ & Ganjil & 69,25 \\
\hline \multicolumn{3}{c}{ (Arsip SMP Negeri 3 Karangasem) }
\end{tabular}

Dari hasil observasi di kelas VIIIA SMP Negeri 3 Karangasem pada tanggal 22 Maret 2013 diperoleh gambaran bahwa: 1) siswa masih malu dalam mengomunikasikan gagasannya dan masih ragu-ragu dalam mengemukakan permasalahannya ketika siswa tersebut menghadapi suatu masalah dalam memecahkan persoalan matematika. Ketika ada masalah yang disajikan dalam bentuk lain (tidak sesuai dengan contoh yang diberikan) siswa masih bingung bagaimana menyelesaikannya. Hal ini mencerminkan penalaran siswa dalam proses pembelajaran relatif rendah;2) siswa belum mampu menyampaikan atau mengomunikasikan ide atau pendapatnya. Pendapat yang 
disampaikan oleh siswa sering kurang terstruktur sehingga sulit dipahami oleh guru maupun temannya. Berdasarka hasil wawancara dengan beberapa orang siswa kelas VIIIA SMP Negeri 3 Karangasem diperoleh gambaran bahwa siswa menganggap pelajaran matematika sebagai pelajaran yang membosankan, banyak menghapal rumus serta kurang menyentuh kehidupan sehari-hari siswa.

Berbagai usaha telah dilakukan guru dalam mengatasi permasalahan tersebut di atas, seperti melakukan diskusi atau tanya jawab dalam kelas. Tetapi usaha itu belum mampu merangsang siswa untuk aktif dalam pembelajaran, karena siswa yang menjawab pertanyaan guru, cenderung didominasi oleh beberapa orang saja. Sedangkan siswa yang lain hanya mendengarkan dan mencatat informasi yang disampaikan temannya. Usaha lain yang dilakukan guru adalah dengan melaksanakan pembelajaran dalam setting kelompok kecil. Akan tetapi siswa lebih banyak bekerja sendiri-sendiri dalam menyelesaikan soal-soal yang diberikan guru, kurang adanya diskusi antar siswa. Usahausaha yang telah dilakukan guru tampaknya belum membuahkan hasil yang optimal dalam meningkatkan kemampuan penalaran dan komunikasi matematika siswa. Hal ini dapat dilihat dari data tes ulangan harian kelas VIIIA pada semester genap tahun ajaran 2012/2013 materi garis dan sudut. Adapun data tes ulangan harian tersebut dapat dilihat pada tabel berikut.

Tabel 2. Data Hasil Tes Ulangan Harian Kelas VIIIA

\begin{tabular}{lc}
\hline & $\begin{array}{c}\text { Kemampuan } \\
\text { Penalaran dan } \\
\text { Komunikasi } \\
\text { Matematika }\end{array}$ \\
\hline Rata-rata Nilai & 5,71 \\
\hline Daya Serap & $57,1 \%$ \\
\hline Ketuntasan & $25,71 \%$ \\
\hline
\end{tabular}

Dalam kegiatan pembelajaran hendaknya siswa diajak untuk berinteraksi dengan seluruh peserta belajar yang ada dalam kelas. Interaksi ini harus berlangsung secara berkesinambungan sehingga guru tidak terlalu mendominasi kegiatan pembelajaran yang berlangsung. Ini akan memberikan kesempatan kepada siswa untuk mengembangkan kemampuan penalarannya. Selain itu dalam pembelajaran perlu diberikan soal-soal pemecahan masalah yang menuntut siswa untuk bernalar dan 
mengomunikasikan ide-ide yang mereka miliki.

Model pembelajaran Learning Cycle "5E" merupakan salah satu model pembelajaran yang memberikan kesempatan kepada siswa untuk mengoptimalkan cara belajar dan mengembangkan daya nalar siswa (Dasna dan Fajaroh, 2006). Dalam model pembelajaran Learning Cycle "5E" dilakukan kegiatan-kegiatan yaitu berusaha untuk membangkitkan minat siswa pada pelajaran matematika (engagement), memberikan kesempatan kepada siswa untuk memanfaatkan panca indera mereka semaksimal mungkin dalam berinteraksi dengan lingkungan melalui kegiatan telaah literatur (exploration), memberikan kesempatan yang luas kepada siswa untuk menyampaikan ide atau gagasan yang mereka miliki melalui kegiatan diskusi (explaination), mengajak siswa mengaplikasikan konsep-konsep yang mereka dapatkan dengan mengerjakan soal-soal pemecahan masalah (elaboration) dan terdapat suatu tes akhir untuk mengetahui sejauh mana tingkat pemahaman siswa terhadap konsep yang telah dipelajari (evaluation). Learning Cycle "5E" merupakan perwujudan dari filosofi konstruktivisme, pengetahuan dibangun dalam pikiran pebelajar. Beberapa keuntungan diterapkannya pembelajaran Learning Cycle "5E" yaitu: 1) pembelajaran menjadi berpusat pada siswa (studentcentered); 2) proses pembelajaran menjadi lebih bermakna karena mengutamakan pengalaman nyata; 3) menghindarkan siswa dari cara belajar tradisional yang cenderung menghafal; 4) memungkinkan siswa untuk mengasimilasi dan mengakomodasi pengetahuan lewat pemecahan masalah dan informasi yang didapat; dan 5) membentuk siswa yang aktif, kritis, dan kreatif. Learning Cycle "5E" pada dasarnya sesuai dengan teori konstruktivis Vigostky dan teori belajar bermakna Ausubel. Vigostky menekankan adanya hakikat sosial dari belajar dan menyarankan menggunakan kelompok-kelompok belajar dengan kemampuan yang berbeda-beda untuk mengupayakan perubahan konseptual. Sedangkan Ausubel menekankan pada belajar bermakna dan pentingnya pengulangan sebelum belajar dimulai. Dalam melakukan diskusi, siswa akan mempunyai kesempatan 
yang lebih luas untuk mengemukakan pendapatnya dan siswa akan menemukan konsep berdasarkan pemahamannya sendiri. Dalam berdiskusi, siswa memerlukan sarana yang salah satunya berupa Lembar Kerja Siswa (LKS) sebagai acuan yang dapat menuntun siswa dalam memahami masalah matematika. Dalam hal ini yang dimaksudkan adalah LKS terstruktur, dalam LKS ini ringkasan materi ajar disusun secara sistematis, kemudian diikuti dengan penyajian contoh soal dan soal-soal mulai dari yang mudah sampai yang sukar serta soal-soal pengayaan (Pujawan dkk, 2001).

\section{METODE PENELITIAN}

Penelitian yang akan dilaksanakan termasuk jenis penelitian tindakan kelas (Classroom Action Research) yang secara umum bertujuan meningkatkan dan memperbaiki proses kegiatan pembelajaran. Penelitian ini direncanakan dalam 3 siklus dimana setiap siklus melibatkan 4 tahap yaitu tahap perencanaan, pelaksanaan tindakan, observasi dan evaluasi serta refleksi (Kemmis and Taggart, 1990). Penelitian dilaksanakan di SMP Negeri 3 Karangasem. Subjek penelitian ini adalah siswa kelas VIIIA SMP Negeri 3 Karangasem tahun ajaran 2013/2014 yang berjumlah 30 orang dengan 20 orang siswa laki-laki dan 10 orang siswa perempuan.

Objek yang ditangani dalam penelitian ini adalah kemampuan penalaran dan komunikasi matematika siswa dan respons siswa terhadap model pembelajaran Learning Cycle "5E" berbantuan LKS Terstruktur.

Adapun hal-hal pokok yang dilaksanakan pada tahap tindakan dalam siklus penelitian ini adalah sebagai berikut. 1) Melaksanakan pembelajaran sesuai dengan model pembelajaran Learning Cycle "5E" berbantuan LKS Terstruktur; 2) Melaksanakan tes kemampuan penalaran dan komunikasi untuk siklus

Tabel 3. Pembelajaran dengan Model Pembelajaran Learning Cycle "5E" berbantuan LKS Terstruktur.

\begin{tabular}{ccl}
\hline Fase & \multicolumn{1}{c}{ Aktivitas Guru } & \multicolumn{1}{c}{ Aktivitas Siswa } \\
\hline Pendahuluan & Guru menenangkan situasi kelas dan & Memperhatikan informasi \\
& menyampaikan tujuan dan indikator \\
pembelajaran. & yang diberikan oleh guru \\
& & $\begin{array}{l}\text { berkaitan dengan indikator } \\
\text { pembelajaran yang } \\
\text { disampaikan }\end{array}$ \\
\hline
\end{tabular}




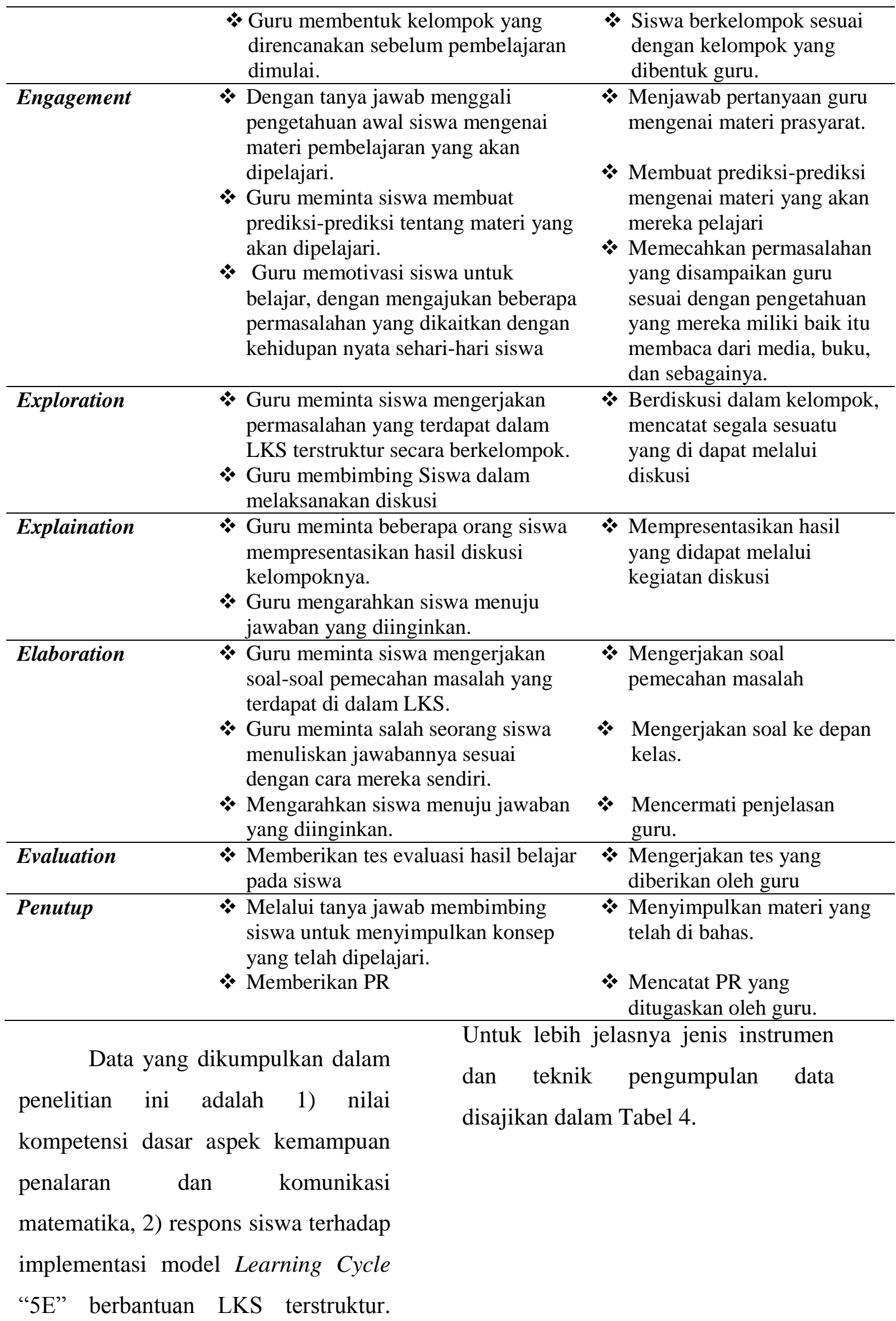


Tabel. 4 Instrumen dan Teknik Pengumpulan Data

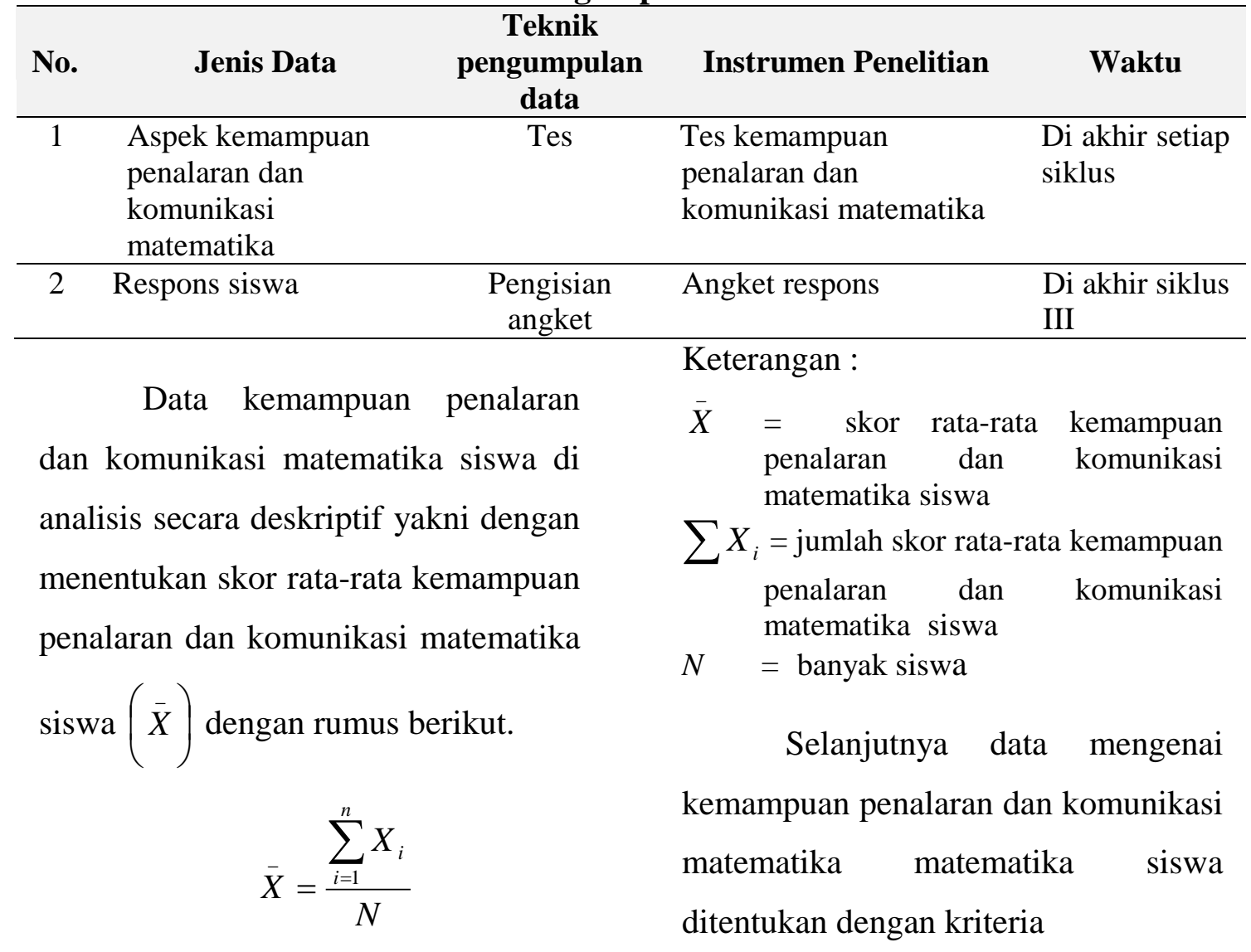

Tabel. 5 Kriteria Umum Penggolongan Kemampuan Penalaran dan Komunikasi Matematika

\begin{tabular}{clc}
\hline No & \multicolumn{1}{c}{ Kriteria } & Kategori \\
\hline 1 & $\bar{X} \geq M_{i}+1,5 S d_{i}$ & Sangat Baik \\
\hline 2 & $M_{i}+0,5 S d_{i} \leq \bar{X}<M_{i}+1,5 S d_{i}$ & Baik \\
\hline 3 & $M_{i}-0,5 S d_{i} \leq \bar{X}<M_{i}+0,5 S d_{i}$ & Cukup \\
\hline 4 & $M_{i}-1,5 S d_{i} \leq \bar{X}<M_{i}-0,5 S d_{i}$ & Kurang \\
\hline 5 & $\bar{X} \leq M_{i}-1,5 S d_{i}$ & Sangat kurang \\
\hline
\end{tabular}

(dimodifikasi dari Ratumanan dan Theresia, 2003)

Dengan, Mean Ideal $\left(M_{i}\right)=\frac{1}{2}($ skor maksimum + skor minimum $)$

Standar deviasi Ideal $\left(S d_{i}\right)=\frac{1}{6}$ (skor maksimum - skor minimum)

Untuk mengetahui respons siswa terhadap pembelajaran yang diterapkan akan dilakukan analisis deskriptif terhadap pendapat siswa yang dituangkan dalam angket respons siswa. Data respons siswa dianalisis berdasarkan rata-rata skor respons 
siswa $(\bar{P})$, mean $\left(M_{i}\right)$ dan standar deviasi $\left(S d_{i}\right)$ dimana:

$\bar{P}$ adalah jumlah skor pendapat siswa perbanyaknya siswa

$M_{i}$ adalah $\frac{1}{2}$ (Skor tertinggi ideal + skor terendah ideal)

$S d_{i}$ adalah $\frac{1}{6}$ (Skor tertinggi ideal skor terendah ideal)

Dari data respons siswa yang dikumpulkan akan dihitung rata-rata tanggapan $(\bar{P})$ dengan rumus:

$$
\bar{P}=\frac{\sum_{i=1}^{n} P_{i}}{n}
$$

Keterangan :

$\bar{P} \quad=$ rata-rata skor respons siswa

$\sum P_{i}=$ jumlah skor rata-rata respons siswa

$n$ = banyaknya siswa

Rata-rata respons siswa yang diperoleh akan dicocokkan dengan penggolongan kriteria/tingkatan sebagai berikut.

Tabel. 6 Kriteria Umum Penggolongan Respons Siswa

\begin{tabular}{clc} 
No & \multicolumn{1}{c}{ Kriteria } & Kategori \\
\hline 1 & $\bar{P} \geq M_{i}+1,5 S d_{i}$ & Sangat positif \\
\hline 2 & $M_{i}+0,5 S d_{i} \leq \bar{P}<M_{i}+1,5 S d_{i}$ & Positif \\
\hline 3 & $M_{i}-0,5 S d_{i} \leq \bar{P}<M_{i}+0,5 S d_{i}$ & Cukup Positif \\
\hline 4 & $M_{i}-1,5 S d_{i} \leq \bar{P}<M_{i}-0,5 S d_{i}$ & Negatif \\
\hline 5 & $\bar{P} \leq M_{i}-1,5 S d_{i}$ & Sangat negatif \\
\hline
\end{tabular}

(dimodifikasi dari Ratumanan dan Theresia, 2003)

HASIL PENELITIAN DAN

PEMBAHASAN

penalaran dan komunikasi matematika

\section{Hasil Penelitian}

Berikut menyajikan ringkasan

hasil penelitian tentang kemampuan

Tabel 7 Kemampuan Penalaran dan Komunikasi Matematika

\begin{tabular}{|c|c|c|c|}
\hline Tahapan & Total Skor & Rata-Rata Skor & Kriteria \\
\hline Siklus I & 669 & 23,06 & Cukup Baik \\
\hline Siklus II & 857 & 28,57 & Baik \\
\hline Siklus III & 1026 & 34,2 & Sangat Baik \\
\hline
\end{tabular}

Data peningkatan rata-rata skor

kemampuan penalaran dan komunikasi

matematika siswa pada Tabel 07

disajikan dalam Gambar 01 berikut. 


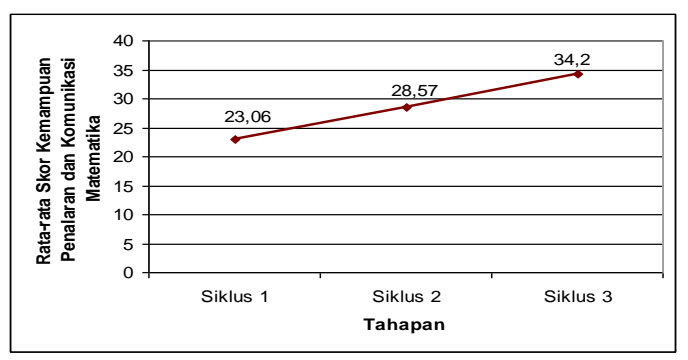

Gambar 1 Peningkatan Rata-Rata Skor Kemampuan Penalaran dan Komunikasi Matematika Siswa pada Siklus I, Siklus II, dan Siklus III

\section{Pembahasan}

Secara kuantitatif, rata-rata skor kemampuan penalaran dan komunikasi matemaika siswa pada siklus I adalah 23,06 (secara kualitatif tergolong "cukup baik"). Dengan demikian secara klasikal kemampuan penalaran dan komunikasi siswa masih belum memenuhi kriteria yang diharapkan.

Belum tercapainya kriteria kemampuan penalaran dan komunikasi matematika yang diharapkan pada siklus I disebabkan oleh adanya beberapa kekurangan pada pelaksanaan tindakan siklus I. Kekurangan-kekurangan yang teridentifikasi pada pelaksanaan tindakan siklus I adalah sebagai berikut. 1) Dalam diskusi kelompok masih terlihat ada siswa yang enggan untuk berdiskusi dengan teman sekelompoknya saat menjawab permasalahan yang ada dalam LKS. Siswa yang mempunyai kemampuan akademik kurang tidak berani mengungkapkan pendapatnya serta siswa yang memiliki kemampuan akademik baik, ragu-ragu untuk memberikan penjelasan kepada temannya. 2) Siswa terlihat masih kaku, tegang, dan kurang santai dalam mengikuti proses pembelajaran. Ini disebabkan karena guru yang mengajar lain dari biasanya. 3) Pada saat pengerjaan LKS banyak kelompok yang kurang disiplin, hal ini terlihat dari pengerjaan LKS yang melebihi batas waktu. 4) Jawaban yang diberikan siswa masih kurang terstruktur, banyak siswa yang belum terbiasa untuk menuliskan apa yang diketahui dan ditanyakan dalam soal. Siswa juga belum terbiasa menuliskan rencana penyelesaian soal. 5) Sebagian besar siswa belum terbiasa menyimpulkan konsep-konsep yang telah dipelajari. Siswa masih mengalami kesulitan dalam membuat simpulan yang sistematis dan sesuai dengan yang diharapkan.

Bertolak dari kekurangankekurangan yang hadapi pada siklus I, peneliti bersama dengan guru mendiskusikan perbaikan tindakan 
untuk selanjutnya diterapkan pada siklus II. Perbaikan tindakan yang dilakukan adalah sebagai berikut. 1) Memberikan motivasi kepada setiap kelompok tentang pentingnya kerjasama antar anggota kelompok dalam diskusi; 2) Memberikan motivasi kepada siswa mengenai manfaat dari pembelajaran yang sedang diterapkan guru; 3) Memberikan batas waktu maksimal dalam pengerjaan LKS serta memberikan teguran atau peringatan kepada kelompok yang mengerjakan LKS melebihi batas waktu; 4) Menugaskan setiap siswa untuk mengerjakan kembali permasalahan yang ada pada LKS di rumah; 5) Mengarahkan siswa dalam membuat simpulan dengan memberikan pertanyaan pancingan yang mengarah pada simpulan yang diharapkan.

Selain kekurangan-kekurangan yang terjadi pada siklus I terdapat suatu kelebihan yang sebaiknya tetap dipertahankan untuk siklus berikutnya, yaitu siswa sudah terlihat aktif dalam mengikuti pembelajaran yang diterapkan guru. Bardasarkan implementasi rancangan pada siklus II yang merupakan perbaikan pada siklus I, secara kuantitatif rata-rata skor hasil tes kemampuan penalaran dan komunikasi matematika mengalami peningkatan dari 23,06 menjadi 28,57 dari kategori "cukup baik" menjadi "baik".

Bertolak dari kekurangankekurangan pada siklus II peneliti bersama guru mendiskusikan perbaikan tindakan untuk selanjutnya diterapkan pada siklus III. Perbaikan tindakan yang dilakukan pada siklus III ini ternyata mampu meningkatkan kemampuan penalaran dan komunikasi matematika siswa. Pada siklus ini ratarata skor kemampuan penalaran dan komunikasi matematika mengalami peningkatan dari siklus II ke siklus III yaitu dari 28,57 menjadi 34,2 ; dari kategori baik menjadi sangat baik.

Terkait dengan respons siswa terhadap implementasi model pembelajaran Learning Cycle "5E" berbantuan LKS terstruktur diketahui $66,67 \%$ siswa merespons sangat positif terhadap pembelajaran yang diterapkan, 26,67 \% memberikan respons positif, dan hanya $6,67 \%$ memberikan respons cukup positif. Secara klasikal rata-rata respons siswa terhadap implementasi model pembelajaran Learning Cycle "5E" berbantuan LKS terstruktur diperoleh 
rata-rata respons siswa adalah 35,7 . Berdasarkan kriteria penggolongan respons siswa secara umum respons siswa terhadap implementasi model pembelajaran Learning Cycle "5E" berbantuan LKS terstruktur tergolong sangat positif. Adanya siswa yang belum menyambut positif diterapkannya pembelajaran ini diduga karena siswa belum terbiasa dengan pembelajaran yang diterapkan oleh guru.

\section{PENUTUP}

\section{Simpulan}

Berdasarkan hasil analisis data dan pembahasan, dapat disimpulkan hal-hal sebagai berikut.

1. Implemenatsi model pembelajaran Learning Cycle "5E" mampu meningkatkan kemampuan penalaran dan komunikasi matematika siswa kelas VIIIA SMP Negeri 3 Karangasem baik secara kualitatif maupun kuantitatif. Pada siklus I rata-rata skor kemampuan penalaran dan komunikasi matematika siswa adalah 23,06 (cukup baik) dan meningkat menjadi 28,57 (baik) pada siklus II, menjadi 34,2 (sangat baik) pada siklus III.
2. Siswa Kelas VIIIA SMP Negeri 3 Karangasem secara klasikal memberikan respons yang sangat positif terhadap implementasi model pembelajaran Learning Cycle "5E" berbantuan LKS terstrukur. Secara individual, $66,67 \%$ siswa merespons sangat positif terhadap pembelajaran yang diterapkan, 26,67 \% memberikan respons positif, dan hanya $6,67 \%$ memberikan respons cukup positif.

\section{Saran}

Berdasarkan hasil penelitian ini, disampaikan saran sebagai berikut.

1. Diharapkan kepada guru Kelas VIIIA untuk tetap mengimplementasikan model pembelajaran Learning Cycle " $5 \mathrm{E}$ " berbantuan LKS terstrukur minimal dengan menggunakan skenario pembelajaran seperti yang diterapkan dalam penelitian ini sebagai salah satu alternatif dalam melaksanakan pembelajaran yang lebih inovatif.

2. Kepada pembaca yang berminat untuk mengadakan penelitian lebih lanjut mengenai implementasi model pembelajaran Learning Cycle "5E" pada bidang 
ilmu matematika maupun pada bidang ilmu lainnya yang sesuai, agar memperhatikan segala kendala-kendala yang peneliti alami sebagai bahan pertimbangan untuk perbaikan dan penyempurnaan pelaksanaan penelitian.

\section{DAFTAR PUSTAKA}

Ansari, B. I. 2003. Model Pembelajaran Berbasis Komunikatif dengan Strategi Think-Talk-Write dalam rangka Menumbuhkembangkan

Kemampuan Pemahaman dan Komunikasi Matematika Siswa SMU. Makalah. Disajikan dalam The $6^{\text {th }}$ National Seminar On Science and Mathematics Education. Bandung.

Depdiknas. 2004. Pedoman Khusus Pengembangan Sistem Penilaian Berbasis Kompetensi SMP. Jakarta: Depdiknas.

Kemmis dan Taggart. 1990. The Action Research Planner. Civtoria: Deakin University Press.

Pujawan, dkk. 2001. Pengembangan Model Pembelajaran Kooperatif dalam Meningkatkan Kualitas Pembelajaran dan hasil Belajar Siswa SLTP. Usulan Reseach Grant (tidak diterbitkan). IKIP Negeri Singaraja.

Ratumanan, T. G. dan Theresia L. 2003. Evaluasi Hasil Belajar yang relevan dengan Kurikulum Berbasis Kompetensi. Surabaya: Unesa University Press.

Subando, J. 2005. Pembelajaran Matematika dengan Dasar Kurikulum Berbasis Kompetensi
Pada Siswa Sekolah Menengah Pertama. Online (http://jokobando.tripod.com/ind ex_files/pembat.htm, diakses 30 Desember 2007). 